\title{
Melatonin, insulin and adrenaline in the blood of rabbit kits that survived prenatal hypoxia: Hormone dynamics at physical exertion
}

\author{
ALI ALIYEV, KONUL HASANOVA*, FATMA ALIYEVA, RUCHANQIZ BABAYEVA, \\ SEVINJ IBRAHIMOVA, ELVIN HUSEYNOV
}

\begin{abstract}
Department of Human and Animal Physiology, Faculty of Biology, Baku State University, Baku, Azerbaijan *Animal and Human Physiology Department, Baku State University, Baku, Azerbaijan
\end{abstract}

Aliyev A., Hasanova K., Aliyeva F., Babayeva R., Ibrahimova S., Huseynov E. Melatonin, insulin and adrenaline in the blood of rabbit kits that survived prenatal hypoxia: Hormone dynamics at physical exertion

Summary

The purpose of the research was to study the dynamics of melatonin, insulin and adrenaline in the blood of rabbit kits (prior and subsequent to prenatal hypoxia) at various stages of fetal growth and development, as well as to study the ability of kits to withstand physical exertion of various intensity and duration in light and darkness. This research shows that the melatonin level decreases with increasing insulin, and increases with decreasing insulin in animals of different ages kept under conditions of constant light and constant darkness, whereas the level of adrenaline decreases at physical exertion, but increases with a decrease in melatonin. This research confirms the inverse relationship between the levels of melatonin and insulin and between the levels of melatonin and adrenaline. Kits kept in constant darkness showed increased melatonin levels, which, by contrast, decreased under conditions of constant light.

Keywords: prenatal hypoxia, early postnatal period, melatonin, insulin, adrenalin

Melatonin is involved in regulating the functions of the central and autonomic nervous systems, endocrine organs, the immune system and their daily rhythmic activity (3-5). Hypoxia causes a complex restructuring of the functioning of various body systems, which is aimed at ensuring the delivery of the required amount of oxygen to the tissues (6-8). Adaptation to hypoxia has a significant effect on the central nervous system, central hemodynamics, microcirculation in various organs, oxygen metabolism, free radical lipid oxidation, the main enzymes of detoxification systems and immunity $(23,24)$. Hypoxia causes a wide range of pathogenic, mutational and adaptive-compensatory changes at the level of various systems. Such changes in prenatal and early postnatal ontogenesis are essential for the survival of the organism, as well as for the formation of various behavioral responses. Stress, such as hypoxia, various physical activities and the effect of light exposure, are one of the most pressing problems of modern medicine and biology $(1,2)$. It is known that acute or chronic effects of stressors on the mammalian organism often lead to various forms of metabolic disorders $(1,2,9-12)$. In particular, stress (hypoxia, physical exercise and photoperiodism) is accompanied by changes in the production of insulin and glucagon, the synthesis of glucose and melatonin, and consequently, a change in adrenaline $(3,7)$.

There are few data on the relationship between central/peripheral innervation and the photoregulation of the pineal gland $(5,21)$. The pineal gland is assumed to receive central innervation from the epithalamic region as a reaction to stress (22). Melatonin forms then in pineal cells on the background of fasting and in constant light (36). If sympathetic nerve fibers release less norepinephrine (12-15), melatonin forms in greater amounts, indicating a possible role of non-adrenergic innervations, which takes place without a direct participation of adrenergic fibers in the process of regulating the response of the pineal gland to stressors (16-19).

Nature has provided living organisms with a device capable of perceiving light and transforming it into signals that control bodily rhythms. The central part of this device is the upper appendage of the brain, the epiphysis, or the pineal gland $(32,34,37)$. Its main 
function is to detect daylight and darkness, and to tell the brain how to change to maintain physiological rhythms and ensure adaptation to the environment (21-24).

The biological effect of extrapineal melatonin is realized directly at the site of its synthesis. Because hormones are synthesized by non-hormonal cells, one can assume they appear before the separation of the endocrine glands. The question of whether hormone synthesis is photo-independent remains open (36, 38-40).

If we imagine the epiphysis as a biological clock of the organism, then melatonin can be compared to the swinging weight: when the period of a swing decreases, the clock stops $(4,12,15,26,41)$. Perhaps, the epiphysis is more like a sundial, and melatonin acts as the shadow cast onto the dial by the gnomon. When the sun is high, the shadow is short (the melatonin level is minimal), but in the middle of the night, the pineal gland synthesizes and secretes the maximum amount of melatonin. Some works show that disturbed periodicity can significantly shorten the life span. American researchers $M$. Hurd and M. Ralph discovered that golden hamsters with a special mutation in the tau gene responsible for generating rhythmic signals in the suprachiasmatic nucleus lived a 20\% shorter life than the control ones (25-31). With healthy hypothalamic cells transplanted into mutant hamster brains, the normal lifespan was restored. The destruction of suprachiasmatic nuclei leads to a decrease in the life span of animals. The impaired function of some circadian genes causes premature aging and various pathological conditions $(4,16,17,26)$. This hormone protects nuclear DNA, proteins and lipids. The antioxidant activity of melatonin is associated with its ability to neutralize free radicals, including those formed from lipid peroxidation or from the activation of glutathione peroxidase, a powerful endogenous factor of enzymatic protection against radical oxidation $(19,39)$. Different trials proved that melatonin neutralizes hydroxyl radicals more actively than antioxidants do, such as glutathione and mannitol. Moreover, it is twice as strong as vitamin $E$ in neutralizing peroxyl radicals $(14,17)$.

The epiphysis is an important element of the body's anti-stress defense system, in which melatonin plays an important role as a nonspecific defense factor (4, 7, 9, 27, 34). Highly organized animals and humans are able to experience negative emotions, which may spark the feeling of stress. Melatonin helps to reduce emotional reactivity. A negative effect of stress is increased free-radical oxidation, including lipid peroxidation, which damages cell membranes $(14,17)$. Stress comes with some serious changes in the endocrine sphere, which affect primarily the hypothalamic pituitary adrenal system. In this case, melatonin acts as a backup element - the hormone is synthesized for endocrine regulation only in the case of serious abnormalities of the adrenal function $(27,29)$. There is ample evidence of adverse effects of chronic stress on the immune system. In particular, individuals suffering from a traumatic situation for a period of time have a lower level of T-lymphocytes in their blood $(2,6,9,27,29,41)$. In this situation, melatonin has both a direct effect on immunocompetent cells and an effect mediated indirectly through the hypothalamus and other neuroendocrine systems $(2,11,16,36)$. Even though biological rhythms are regulated more by the suprachiasmatic nucleus than by the epiphysis, both of these bodily parts run on melatonin (SCN cells are responsive to melatonin), which can slow down a fast clock $(22,38,41)$.

The possible inhibitory effect of melatonin on carcinogenesis and aging have been recently on the front burner of discussion $(3,5,9,19,28,34,39)$. This hormone has been found to be effective in preventing aging and cancer from occurring at the systemic, tissue, cellular and subcellular levels. At the systemic level, melatonin reduces the production of hormones that promote the said processes, stimulates the immune surveillance and prevents the metabolic syndrome (14, 30 ). At the same time, this causes the suppression of oxygen free radicals, as well as the activation of the antioxidant protection system $(27,28,41)$.

The epiphysis and the pancreas occupy an important place in the endocrine hormonal regulation of metabolic processes and physiological functions $(3,29)$. The pineal is one of the leading links in the formation of daily biorhythms and homeostatic parameters. The hormone provided by the pineal gland - melatonin together with epiphyseal neuropeptides, is involved in the light-dark regulation of bodily functions, while pancreatic hormones have specific effects at the molecular and cellular homeostatic levels $(24,28)$. There is indirect evidence of melatonin being conjugated to insulin and adrenaline at the level of glucose homeostasis, especially when physiological parameters change as a result of body adaptation (9).

Living organisms can survive in a changing environment only thanks to the inborn programs of adaptation to light-dark cycles and thanks to mechanisms that ensure the proper functioning of those programs $(26,36)$. The controlling effect in this case is performed by the photoperiod, also called day length. The brain reacts to the length of day and night by releasing different amounts of melatonin $(1,29,36)$. The melatonergic system is regarded as an integral element of the body clock $(1,39)$, whose typical features are (13) 1) light sensitivity, 2) the circadian rhythm (with maximum melatonin synthesized at night) and 3) chronic progressive weakening with age. Some believe that the melatonergic system is involved in the development of certain diseases (11). It can be assumed that the components of the melatonergic system adapt not only to adverse environmental impacts that follow light-dark cycles, but also to independent dangers, such as those that occur at hypoxia $(1,2,11,16,36)$. 
Melatonin synthesis is a frequent response to hypoxia $(3,6)$, apparently because of molecular and cellular changes in the epiphysis $(29,35,36,40)$. There is little reliable information about pancreatic reactions to oxygen starvation, especially from studies on animals that underwent oxygen deprivation prenatally $(19,23$, $28,39,41)$. Studies show that animals that had cases of prenatal hypoxia in previous generations have some pathological changes of varying severity. Thus, the purpose of this research was to study the dynamics of melatonin, insulin and adrenaline in the blood of rabbit kits (prior and subsequent to prenatal hypoxia) at various stages of fetal growth and development and to study the ability of kits to withstand physical exertion of various intensity and duration in light and darkness. This study was performed on 30-day-old kits that had survived prenatal hypoxia and were subjected to stress factors, such as short-term and long-term physical exertion, light and darkness.

\section{Material and methods}

This study used 1-month-old rabbits of the Chinchilla breed obtained from adult rabbits who survived under conditions of several hypoxia at different stages of pregnancy (germinal 1-10, pre-pubertal 10-20 and fetal 20-30 periods of development). In this article, we present the results of pre-pubertal hypoxia.

Animals were divided into two groups: control and experimental. We used 72 control and 216 experimental rabbits for each series.

This study was performed on 1-month-old Chinchilla kits from normal pregnancy and on kits that had survived hypoxia at different stages of pregnancy (1-10 days, 10-20 days and 20-30 days).

Khvatov B. P. and Khvatova Ye. M suggested exposing rabbits to hypoxia of $7 \% \mathrm{O}_{2}$ in $\mathrm{N}_{2}$ (31-32). Khvatov did a research on fetal development by periods and developed a method that is currently used to expose pregnant rabbits to hypoxia at different stages of pregnancy. This study uses the Khvatova's method as well. The animals were kept in a chamber, where they inhaled an oxygen-nitrogen mix for 20 minutes. Blood was taken from the marginal ear vein of normal kits and kits that had survived prenatal hypoxia. It was then centrifuged for 20 minutes at $1500 \mathrm{rpm}$ to obtain plasma. An EDTA solution was added to plasma samples to maintain the molecular integrity of hormones (melatonin and insulin). The hormone levels were determined by an enzyme-linked immunosorbent assay (ELISA) using the CUSABIO ELISA kit. Quantitative measurements were performed using a Stat Fax 303 Plus Analyzer (Awareness Technologies Inc.) at $450 \mathrm{~nm}$ or $630 \mathrm{~nm}$ wavelength set for hormones. Further, the kits underwent 5-minute, 20-minute and 40-minute periods of physical exertion (treadmill running), after which their blood was taken to determine the levels of melatonin, insulin and adrenaline. The group of 30-day-old rabbits was divided into 2 groups: the first group spent 10 days under conditions of constant light, while the second group was kept under conditions of complete darkness.

The research was performed under the Helsinki Declaration on the Humane Treatment of Animals and under USSR Rules for Carrying Out an Analysis Using Experimental Animals.

The resulting data were processed by statistical methods in Microsoft Excel, and then variability and reliability were measured according to P.F. Rokitsky $(33,35)$.

\section{Results and discussion}

Results are shown in Tables 1 and 2. Table 1 shows blood levels of melatonin, insulin, and adrenaline in 30 -day-old normal kits, which were $61.98 \pm 0.33 \mathrm{U} / \mathrm{ml}$, $49.64 \pm 0 \mathrm{U} / \mathrm{ml}$ and $408.44 \pm 0.001 \mathrm{U} / \mathrm{ml}$, respectively, $\mathrm{P}<0.001$. After a short 5-minute period of physical exertion, these levels changed to $28.28 \pm 1.49 \mathrm{U} / \mathrm{ml}$, $32.8 \pm 0.04 \mathrm{U} / \mathrm{ml}$ and $406 \pm 0.04 \mathrm{U} / \mathrm{ml}$, respectively, $\mathrm{P}<0.001$. After a 20 -minute period of physical exertion, these levels changed to $136.9 \pm 0 \mathrm{U} / \mathrm{ml}$, $33.6 \pm 0.01 \mathrm{U} / \mathrm{ml}$ and $792.25 \pm 0 \mathrm{U} / \mathrm{ml}$, respectively, $\mathrm{P}<0.001$. After a 40-minute period of physical exertion, these levels were $46.8 \pm 0 \mathrm{U} / \mathrm{ml}, 69.68 \pm 0.09$ $\mathrm{U} / \mathrm{ml}$ and $780.3 \pm 0.16 \mathrm{U} / \mathrm{ml}$, respectively, $\mathrm{P}<0.001$.

Normal 30-day-old kittens that had spent 10 days in constant light (first group) had the following blood levels of melatonin, insulin and adrenaline: $75.56 \pm 0$ $\mathrm{U} / \mathrm{ml}, 152.1 \pm 0 \mathrm{U} / \mathrm{ml}$ and $226.6 \pm 0.08 \mathrm{U} / \mathrm{ml}$, respectively, $\mathrm{P}<0.001$. For kits that had spent 10 days in complete darkness (second group), these levels were $105.38 \pm 0.01 \mathrm{U} / \mathrm{ml}, 345.6 \pm 0.016 \mathrm{U} / \mathrm{ml}$ and 214.5 $\pm 0.04 \mathrm{U} / \mathrm{ml}$, respectively, $\mathrm{P}<0.001$.

After a short 5-minute period of physical exertion, these levels changed in the first group to $64.4 \pm 0.08$ $\mathrm{U} / \mathrm{ml}, 119.8 \pm 0 \mathrm{U} / \mathrm{ml}(\mathrm{P}<0.001)$ and $304.3 \pm 0.2$ $\mathrm{U} / \mathrm{ml}(\mathrm{P}<0.01)$, respectively. After a 20 -minute period of physical exertion, these levels changed to 53.68

Tab. 1. Blood levels of melatonin, insulin and adrenaline in 30-day-old normal kits: measurements taken after exposure to constant light/dark and after physical exertion

\begin{tabular}{|c|c|c|c|c|c|c|c|c|c|c|c|c|}
\hline \multirow{2}{*}{ Hormone } & \multicolumn{4}{|c|}{ Norm + PE } & \multicolumn{4}{|c|}{ Norm + Light + PE } & \multicolumn{4}{|c|}{ Norm + Dark + PE } \\
\hline & Norm & $5 \mathrm{~min}$ & $20 \mathrm{~min}$ & $40 \mathrm{~min}$ & Light & $5 \mathrm{~min}$ & $20 \mathrm{~min}$ & $40 \mathrm{~min}$ & Dark & $5 \mathrm{~min}$ & $20 \mathrm{~min}$ & $40 \mathrm{~min}$ \\
\hline M & $\begin{array}{c}61.98 \\
\pm 0.33^{* * *}\end{array}$ & $\begin{array}{c}28.28 \\
\pm 1.49 * * *\end{array}$ & $\begin{array}{r}136.9 \\
\pm 0 * * *\end{array}$ & $\begin{array}{c}46.8 \\
\pm 0 * * *\end{array}$ & $\begin{array}{r}75.56 \\
\pm 0^{* * *}\end{array}$ & $\begin{array}{c}64.4 \\
\pm 0.08 * * *\end{array}$ & $\begin{array}{c}53.68 \\
\pm 0.01^{* * *}\end{array}$ & $\begin{array}{c}42.4 \\
\pm 4.46^{\star}\end{array}$ & $\begin{array}{c}105.38 \\
\pm 0.01^{* * *}\end{array}$ & $\begin{array}{c}88.8 \\
\pm 2.33^{* * *}\end{array}$ & $\begin{array}{c}72.06 \\
\pm 0.01 \text { ** }\end{array}$ & $\begin{array}{c}50.7 \\
\pm 0.94^{\text {* * }}\end{array}$ \\
\hline I & $\begin{array}{c}49.64 \\
\pm 0^{* * *}\end{array}$ & $\begin{array}{c}32.8 \\
\pm 0.04^{* * *}\end{array}$ & $\begin{array}{c}33.68 \\
\pm 0.01 \text { ** }\end{array}$ & $\begin{array}{c}69.68 \\
\pm 0.09 * * *\end{array}$ & $\begin{array}{c}152.1 \\
\pm 0 * * *\end{array}$ & $\begin{array}{c}119.4 \\
\pm 0 * * *\end{array}$ & $\begin{array}{c}9.43 \\
\pm 0.16^{* * *}\end{array}$ & $\begin{array}{c}76.58 \\
\pm 0.01 \text { *** }\end{array}$ & $\begin{array}{c}345.6 \\
\pm 0.016^{* * *}\end{array}$ & $\begin{array}{l}222.18 \\
\pm 0 * * *\end{array}$ & $\begin{array}{c}85.13 \\
\pm 0^{* * *}\end{array}$ & $\begin{array}{c}167.2 \\
\pm 0.04^{* * *}\end{array}$ \\
\hline A & $\begin{array}{c}408.44 \\
\pm 0.001^{* * *}\end{array}$ & $\begin{array}{c}406.9 \\
\pm 0.04^{* * *}\end{array}$ & $\begin{array}{l}792.25 \\
\pm 0^{* * *}\end{array}$ & $\begin{array}{c}780.3 \\
\pm 0.16^{* * *}\end{array}$ & $\begin{array}{c}226.6 \\
\pm 0.08^{* * *}\end{array}$ & $\begin{array}{c}304.3 \\
\pm 0.2^{* * *}\end{array}$ & $\begin{array}{c}643.76 \\
\pm 0.04^{* * *}\end{array}$ & $\begin{array}{c}753.5 \\
\pm 1.47^{* * *}\end{array}$ & $\begin{array}{c}214.5 \\
\pm 0.04^{* * *}\end{array}$ & $\begin{array}{c}579.5 \\
\pm 0.81^{* * *}\end{array}$ & $\begin{array}{c}669.01 \\
\pm 0.01^{* * *}\end{array}$ & $\begin{array}{c}776.45 \\
\pm 0.07^{* * *}\end{array}$ \\
\hline
\end{tabular}


Tab. 2. Blood levels of melatonin, insulin and adrenaline in 30-day-old normal kits that had survived prenatal hypoxia: measurements taken after exposure to constant light/dark and after physical exertion

\begin{tabular}{|c|c|c|c|c|c|c|c|c|c|c|c|c|}
\hline \multirow{2}{*}{ Hormone } & \multicolumn{4}{|c|}{ Hypoxia + PE } & \multicolumn{4}{|c|}{ Hypoxia + Light + PE } & \multicolumn{4}{|c|}{ Hypoxia + Dark + PE } \\
\hline & Norm & $5 \mathrm{~min}$ & $20 \mathrm{~min}$ & $40 \mathrm{~min}$ & Light & $5 \mathrm{~min}$ & $20 \mathrm{~min}$ & $40 \mathrm{~min}$ & Dark & $5 \mathrm{~min}$ & $20 \mathrm{~min}$ & $40 \mathrm{~min}$ \\
\hline M & $\begin{array}{c}65.1 \\
\pm 0.04^{* * *}\end{array}$ & $\begin{array}{c}39.36 \\
\pm 0.01^{* * *}\end{array}$ & $\begin{array}{c}39.65 \\
\pm 4.09 * *\end{array}$ & $\begin{array}{c}6.75 \\
\pm 0.69 * * *\end{array}$ & $\begin{array}{c}16.11 \\
\pm 0.02 \text { ** }\end{array}$ & $\begin{array}{c}16.3 \\
\pm 2.23^{\text {* * }}\end{array}$ & $\begin{array}{c}13.68 \\
\pm 1.45^{*}\end{array}$ & $\begin{array}{c}59.5 \\
\pm 0.86^{* * *}\end{array}$ & $\begin{array}{c}109.15 \\
\pm 0.33^{* * *}\end{array}$ & $\begin{array}{c}39.75 \\
\pm 0.24^{* * *}\end{array}$ & $\begin{array}{c}22.05 \\
\pm 0 * * *\end{array}$ & $\begin{array}{c}49.08 \\
\pm 0.004^{* * *}\end{array}$ \\
\hline I & $\begin{array}{c}134.1 \\
\pm 0.2^{* * *}\end{array}$ & $\begin{array}{c}47.9 \\
\pm 0^{* * *}\end{array}$ & $\begin{array}{c}61.06 \\
\pm 3.59 * *\end{array}$ & $\begin{array}{c}86.8 \\
\pm 0.04^{* * *}\end{array}$ & $\begin{array}{c}73.7 \\
\pm 0.49 * * *\end{array}$ & $\begin{array}{c}143.2 \\
\pm 2.75^{* * *}\end{array}$ & $\begin{array}{c}126 \\
\pm 0.01^{*}\end{array}$ & $\begin{array}{c}72 \\
\pm 1.04^{* * *}\end{array}$ & $\begin{array}{c}137.06 \\
\pm 0.016^{\star * *}\end{array}$ & $\begin{array}{c}22.18 \\
\pm 0.008^{* * *}\end{array}$ & $\begin{array}{c}105.16 \\
\pm 0.06^{* * *}\end{array}$ & $\begin{array}{c}147.13 \\
\pm 0.01 \text { ** }\end{array}$ \\
\hline A & $\begin{array}{c}468.9 \\
\pm 0 * * *\end{array}$ & $\begin{array}{c}206.8 \\
\pm 0^{* * *}\end{array}$ & $\begin{aligned} & 221.3 \\
\pm & 4.06^{* *}\end{aligned}$ & $\begin{array}{c}459.2 \\
\pm 0.15^{* * *}\end{array}$ & $\begin{array}{c}534.7 \\
\pm 0.01^{* * *}\end{array}$ & $\begin{array}{c}568.6 \\
\pm 0.73^{* * *}\end{array}$ & $\begin{array}{c}643.18 \\
\pm 0.03^{\star}\end{array}$ & $\begin{array}{c}753.5 \\
\pm 0.04^{* * *}\end{array}$ & $\begin{array}{c}411.4 \\
\pm 0.2^{* * *}\end{array}$ & $\begin{array}{c}583.95 \\
\pm 2.09 * * *\end{array}$ & $\begin{array}{c}669.01 \\
\pm 0.012^{* * *}\end{array}$ & $\begin{array}{l}776.45 \\
\pm 0 * * *\end{array}$ \\
\hline
\end{tabular}

$\pm 0.01 \mathrm{U} / \mathrm{ml}, 94.7 \pm 0.16 \mathrm{U} / \mathrm{ml}$ and $643.3 \pm 0.04 \mathrm{U} / \mathrm{ml}$, respectively, $\mathrm{P}<0.001$. After a 40 -minute period of physical exertion, these levels were $42.4 \pm 4.46 \mathrm{U} / \mathrm{ml}$ $(\mathrm{P}<0.01), 76.58 \pm 0.01 \mathrm{U} / \mathrm{ml}$ and $753.53 \pm 1.47 \mathrm{U} / \mathrm{ml}$ $(\mathrm{P}<0.001)$, respectively.

After a short 5-minute period of physical exertion, these levels changed in the second group to $88.8 \pm 2.33$ $\mathrm{U} / \mathrm{ml}(\mathrm{P}<0.02), 222.8 \pm 0 \mathrm{U} / \mathrm{ml}$ and $579.9 \pm 0.81 \mathrm{U} / \mathrm{ml}$ $(\mathrm{P}<0.001)$, respectively. After a 20 -minute period of physical exertion, these levels changed to 72.06 $\pm 0.01 \mathrm{U} / \mathrm{ml}, 85.13 \pm 0 \mathrm{U} / \mathrm{ml}$ and $669.01 \pm 0.01 \mathrm{U} / \mathrm{ml}$, respectively, $\mathrm{P}<0.001$. After a 40 -minute period of physical exertion, these levels were $50.7 \pm 0.94 \mathrm{U} / \mathrm{ml}$, $167.2 \pm 0.04 \mathrm{U} / \mathrm{ml}$ and $776.45 \pm 0.07 \mathrm{U} / \mathrm{ml}$, respectively, $\mathrm{P}<0.001$.

Table 2 shows blood levels of melatonin, insulin and adrenaline in 30-day-old kits that had survived prenatal hypoxia, which were $65.1 \pm 0.04 \mathrm{U} / \mathrm{ml}, 134.1$ $\pm 0.2 \mathrm{U} / \mathrm{ml}$ and $468 \pm 0 \mathrm{U} / \mathrm{ml}$, respectively, $\mathrm{P}<0.001$. After a short 5-minute period of physical exertion, these levels changed to $39.36 \pm 0.01 \mathrm{U} / \mathrm{ml}, 47.9 \pm 0$ $\mathrm{U} / \mathrm{ml}$ and $206.8 \pm 0 \mathrm{U} / \mathrm{ml}$, respectively, $\mathrm{P}<0.001$. After a 20-minute period of physical exertion, these levels changed to $39.65 \pm 4.09 \mathrm{U} / \mathrm{ml}, 61.06 \pm 3.59$ $\mathrm{U} / \mathrm{ml}$ and $221.3 \pm 4.06 \mathrm{U} / \mathrm{ml}$, respectively, $\mathrm{P}<0.02$. After a 40-minute period of physical exertion, these levels were $6.75 \pm 0.69 \mathrm{U} / \mathrm{ml}, 86.8 \pm 0.04 \mathrm{U} / \mathrm{ml}$ and $459.2 \pm 0.15 \mathrm{U} / \mathrm{ml}$, respectively, $\mathrm{P}<0.001$.

The 30-day-old survivals that had spent 10 days in constant light (first group) had the following blood levels of melatonin, insulin and adrenaline: 16.11 $\pm 0.02 \mathrm{U} / \mathrm{ml}, 73.7 \pm 0.49 \mathrm{U} / \mathrm{ml}$ and $534.7 \pm 0.01 \mathrm{U} / \mathrm{ml}$, respectively, $\mathrm{P}<0.001$. For kits that had spent 10 days in complete darkness (second group), these levels were $109.15 \pm 0.33 \mathrm{U} / \mathrm{ml}, 137.6 \pm 0.016 \mathrm{U} / \mathrm{ml}$ and 411.4 $\pm 0.2 \mathrm{U} / \mathrm{ml}$, respectively, $\mathrm{P}<0.001$.

After a short 5-minute period of physical exertion, these levels changed in the first group to $16.3 \pm 2.23$ $\mathrm{U} / \mathrm{ml}, 143.2 \pm 2.7 \mathrm{U} / \mathrm{ml}$ and $568.2 \pm 0.73 \mathrm{U} / \mathrm{ml}$, respectively, $\mathrm{P}<0.001$. After a 20 -minute period of physical exertion, these levels changed to $13.68 \pm 1.4 \mathrm{U} / \mathrm{ml}$, $126 \pm 0.01 \mathrm{U} / \mathrm{ml}$ and $643.18 \pm 0.03 \mathrm{U} / \mathrm{ml}$, respectively, $\mathrm{P}<0.01$. After a 40 -minute period of physical exertion, these levels were $59.5 \pm 0.86 \mathrm{U} / \mathrm{ml}, 72 \pm 1.04 \mathrm{U} / \mathrm{ml}$ and $753.5 \pm 0.04 \mathrm{U} / \mathrm{ml}$, respectively, $\mathrm{P}<0.001$.

After a short 5-minute period of physical exertion, these levels changed in the second group to 39.75 $\pm 0.24 \mathrm{U} / \mathrm{ml}, 22.8 \pm 0.008 \mathrm{U} / \mathrm{ml}$ and $583.95 \pm 2.09$ $\mathrm{U} / \mathrm{ml}$, respectively, $\mathrm{P}<0.001$. After a 20 -minute period of physical exertion, these levels changed to 22.05 $\pm 0 \mathrm{U} / \mathrm{ml}, 105.7 \pm 0.06 \mathrm{U} / \mathrm{ml}$ and $669.3 \pm 0.012 \mathrm{U} / \mathrm{ml}$, respectively, $\mathrm{P}<0.001$. After a 40 -minute period of physical exertion, these levels were $49.08 \pm 0.004 \mathrm{U} / \mathrm{ml}$, $147.13 \pm 0.01 \mathrm{U} / \mathrm{ml}$ and $776.45 \pm 0 \mathrm{U} / \mathrm{ml}$, respectively, $\mathrm{P}<0.001$.

Thus, the lack of change between light and darkness in a cycle had a modulating effect on hormones. Prenatal hypoxia that takes place within the first 10 days of pregnancy, when internal organs and organ systems are formed, inhibited the pineal function at birth. Physical exertion led to a steady change in the activity of antioxidant enzymes, whose direction remained the same, although the degree differed. The suppression of melatonin synthesis is evidenced by the change in the levels of insulin and adrenaline. According to the literature, light is a desynchronizing factor that causes significant changes in various systems of the body, including the immune system $(5,6,8,9)$.

The suppression of the pineal function, achieved by epiphysectomy or by keeping the subject under conditions of constant light, leads to desynchronization of the circadian rhythms, to accelerated aging of some functional systems, and to the development of certain age-related pathological processes, including cancer. In the long run, this reduces the life span of the animal $(1,2,19,21,28,35,36)$. Light deprivation, which stimulates the function of the pineal gland, has the opposite, geroprotective effect $(11,39)$. Animals that had survived prenatal short-term hypoxia and then kept in constant light for 10 days after birth had different blood levels of melatonin, insulin and adrenaline than normal animals did.

Epiphyseal melatonin inhibits the carcinogenesis of animals both under normal light/dark conditions and in constant light. It prevents pathologies that are associated with age and increases the life span of animals. Melatonin may be a useful agent in preventing cancer, especially in northernmost regions, where polar nights occur during the summer and people leave lights on throughout the entire polar night $(1,2,11,12,16,18$, $31,32,35,36,39)$.

To sum up the first and second sets of experiments, the lack of a change between the light and dark periods, combined with prenatal hypoxia as well as short-term 
and long-term periods of physical exertion that kits undertook after birth, disrupted the postnatal development of physiological systems. Fetal hypoxia leads to stillbirth, so it is challenging for kittens to survive if the doe suffers from hypoxia. At the same time, rabbits in the postnatal period turned out to be more sensitive to light-dark changes, obviously because of the abnormal diurnal rhythm of melatonin synthesis. According to the literature, mother's functional status has a significant effect on the cyclical fluctuations of melatonin in the blood of rats (16). At the stage of fetal growth, information about the cycles of light and dark is conveyed to the fetus from the pregnant female through melatonin, which crosses the placenta (38). In the neonatal period, when the epiphysis function is still weak, melatonin, which comes with mother's milk, has a strong influence (41). The role of maternal circadian rhythms in the formation of offspring's circadian rhythms was demonstrated on rats (37) and hamsters (18) under conditions of damaged suprachiasmatic nuclei of the mother $(16,18,21,24,25,34,37$, $40)$. The said damage caused at early stages of pregnancy (day 7) disrupted the normal $\mathrm{N}$-acetyltransferase rhythm in the epiphysis of 10-day-old offspring. The melatoninergic system occupies an important place in the system of antihypoxic protection of the body, which depends on the duration of the photoperiod. In an organism adapted to hypoxia, a restructuring of the sympathoadrenal system occurs, which is characterized by the hypertrophy of sympathetic neurons, an increase in catecholamine synthesis and catecholamine reserves in the adrenal glands, as well as an increase in cardiac adrenoreactivity. Thus, there is an increase in the reserve capacity of the sympathetic nervous system. It was shown that a course of interval hypoxic training also led to an increase in the power of the mechanisms of autonomic regulation of heart functions at rest due to an increase in the activity of the parasympathetic autonomic nervous system, as well as optimized the degree of shifts in heart rate variability (HRV) during simulated acute hypoxia.

Thus, abundant literature data show that the hormone produced by the pineal gland - melatonin - is synthesized in the dark phase, whereas in the light phase the synthesis of melatonin is insignificant $(3-6,8,31,32)$. Therefore, disturbed light-dark cycles in 30-day-old rabbits, laboratory rats and quails cause changes in the circadian rhythm and metabolic disturbances (4, 12, 35, 37, 38).

Earlier data show that neural and hormonal blood regulation is different during the day, depending on the age of animals, physical exertion and light-dark information.

Unlike constant light, constant darkness stimulates the epiphysis and leads to an increase in melatonin synthesis (41). This effect was confirmed by the present research.
Thus, blood levels of melatonin, insulin and adrenaline in intact animals may increase or decrease after physical exertion, depending on the circadian rhythm. This decrease or increase in blood levels of these hormones in intact animals and animals kept in darkness and light is related to the activation or inhibition of the pineal/hypothalamic/pituitary/adrenal function $(4,6,9,34,36,37)$. The epiphysis acts as an endogenic synchronizer of circadian and seasonal rhythms.

Thus, attempts of the body to adapt to hypoxia have a significant effect on the central nervous system. In an organism adapted to hypoxia, sympathetic neurons become hypertrophied. Additionally, catecholamines are synthesized in greater amounts and accumulate in the adrenal glands. Myocardial adrenoreactivity also increases. Thus, there is an increase in the reserve capacity of the sympathetic nervous system.

Despite the opposite effects of being in constant light and in constant darkness on melatonin synthesis by the epiphysis, hypoxia and physical exertion generally add the same to the effect of both phases. The data obtained show the normal level of melatonin $(61.98$ $\pm 0.33 \mathrm{U} / \mathrm{ml}, \mathrm{P}<0.001)$ increasing to $75.56 \pm 0 \mathrm{U} / \mathrm{ml}$ (light phase) and $105.38 \pm 0.01 \mathrm{U} / \mathrm{ml}$ (dark phase), $\mathrm{P}<0.001$. The lack of change between the light and dark phases affects only those physiological factors that are tied to the circadian rhythm, while others, such as insulin and adrenaline synthesis, depend on the level of epiphyseal melatonin.

Changes in the melatonin level during prenatal hypoxia are related to fluctuations in its synthesis by the pineal gland, influenced by hypoxic disorders in the brain. The change in the content of melatonin during short-term and long-term periods of physical exertion was probably caused by shifts in carbohydrate and energy metabolism. The data obtained show that before physical exertion, the melatonin level in kits that had survived fetal hypoxia was $65.1 \pm 0.04 \mathrm{U} / \mathrm{ml}$, $\mathrm{P}<0.001$. After a short-term period of physical exertion, it changed to $39.36 \pm 0.01 \mathrm{U} / \mathrm{ml}, \mathrm{P}<0.001$, and after a long-term period of physical exertion, it changed to $6.75 \pm 0.69 \mathrm{U} / \mathrm{ml}, \mathrm{P}<0.001$. As for insulin and adrenaline, the mechanism of its change in blood after prenatal hypoxia and after physical exertion is more complex and involves disturbances in glucose homeostasis and in the regulation of the autonomic nervous system. This research allows the conclusion that there is an inverse relationship between the levels of melatonin and insulin and between the levels of melatonin and adrenaline, which suggests the existence of reciprocal relations between these hormones.

According to ample literature data $(2,3,8-13)$, the pineal gland hormone -melatonin - is synthesized mainly in the dark phase, whereas in the light phase its synthesis is insignificant. That is why disturbances in the normal rhythm of light and darkness in 30-dayold rabbits, laboratory rats and quails cause changes in the circadian rhythm and disturbances in metabolic 
processes $(3,5,14-16)$. From the data obtained it can be concluded that the neuro-hormonal regulation of blood changes during the day, depending on the age of the animals, their exposure to exercise and the photoperiodic factor. The effect of constant darkness, in contrast to constant illumination, enhances the activity of the epiphysis and leads to an increase in melatonin synthesis by this gland (34-36). This effect was observed in our series of experiments on the dark phase of the photoperiodic factor.

\section{References}

1. Albarran M. T., Lopez-Burillo S., Pablos M. I., Reiter R. J., Agapito M. T. Endogenous rhythms of melatonin, total antioxidant status and superoxide dismutase activity in several tissues of chick and their inhibition by light. J. Pineal Res. 2001, 30, 227-233.

2. Allegra M., Reiter R. J., Tan D.-X., Gentile C., Tesoriere L., Livrea M. A.: The chemistry of melatonin's interaction with reactive species. J. Pineal Res. 2003 , $34,1-10$

3. Alivev A. H., Khalov R. I., Neymanzade N. K., Mikailova U. T., Aliveva F. A., Aliyev $A$. $V$ : The role of the changes in the state of brain for regulation of some lipid and carbohydrate metabolic processes. NATO Science series. Life Behavioural Sci. 2002, 342, 183-190.

4. Aliyev A. H., Aliyeva F. A., Mamedova K. Q.: Dynamics of some hormones and glucose of blood in rabbits after prenatal hypoxia and subjected to postnatal physical exertion. J. Med. Phyloso., Oxford University Press 2017, 42, 1299 $-1305$

5. Aliyev A. H., Aliyeva F. A., Mammadova S. J., Hamidova J. E.: The influence of physical loading to erythroform indicators in rabbit puppies suffered hypoxia. Internat. J. Biol. Res. 2018, 3, 138-140.

6. Aliyeva F. A., Agayev T. M.: The effect of sugar load on the dynamics of melatonin and glucose in the blood of rabbits undergoing prenatal hypoxia of ontogenesis. J. Probl. Physiol. Biochem. 2015, 33-41.

7. Anisimov $V$. N.: Light pollution, reproductive function and cancer risk. Neuroendocrinol. Lett. 2006, 27, 35-52.

8. Anisimov V. N.: Epiphysis, biorhythms and aging. Adv. Physiol. Sci. 2008, 4, 40-65.

9. Arendt J.: Melatonin and human rhythms. Chronobiology Int. 2006, 1, 21-37.

10. Bella L. D., Gualano L.: Key aspect of melatonin physiology, thirty years of research. Neuroendocrinology Lett. 2006, 27, 425-432.

11. Borjigin J., Zhang L. S., Calinescu A. A.: Circadian regulation of pineal gland rhythmicity. Mol. Cell Endocrinol. 2012, 349, 13-19.

12. Esquifino A. I., Pandi-Perumal S. R., Cardinali D. P.: Circadian organization of the immune response: a role for melatonin. Clin. Appl. Immunology Rev. $2004,4,423-433$.

13. Fowden A. L., Giussani D. A., Forhead A. J.: Endocrine and metabolic programming during intrauterine development. Early Hum. Dev. 2005, 81, 723-734

14. Guerrero J. M., Reiter R. J.: Melatonin-immune system relationship. Cur. Top. Med. Chem. 2002, 2, 167-179.

15. Gussiano D. A., Salinas C. E., Villena M., Blamo C. B.: The role of oxygen in perinatal growth: studies in the chick embrio. Physiol. 2007, 15, 901-197.

16. Hardeland R.: Neurobiology, pathophysiology and treatment of melatonin deficiency and dysfunction. Sci. World J. 2012, Article ID 640389.

17. Hilberg T., Glaser D., Reckhart C., Prasa D., Stürzebecher J., Gabriel H. H.: Pure eccentric exercise doesn't activate blood coagulation. Eur. Appl. Physiology 2005, 94, 718-721.

18. Hurd M. W., Ralph M. R.: The significance of circadian organization for longevity in the golden hamster. J. Biol. Rhytms. 1998, 13, 430-436.

19. Hussain S. A.: Effect of melatonin on cholesterol absorption in rats. J. Pineal Res. 2007, 42, 267.

20. Khvatov B. P.: Fertilization and early stages of fetal development of farm animals. Simferopol 1954.

21. Khvatova E. M., Martynov N. V:: Metabolism in acute hypoxia. Gorkii 1977.

22. Komarov F. I., Rapoport S. I., Malinovskaya N. K., Anisimov V. N.: Melatonin in normal health and in pathology. Medpraktika Publishing House, Moscow 2004, 308

23. La Fleur S. E., Kalsbee K. A., Wortel J., van der Vliet J., Buijs R. M.: Role for the pineal and melatonin in glucose homeostasis: Pinealectomy increases night-time glucose concentrations. J. Neuroendocrinal 2001, 13, 1025-1032.

24. Lerner A. B., Case J. D., Mori W., Wright M. R.: Melatonin in peripheral nerve. J. Nature 1959, 27, 1821-1822.
25.Lerner A., Case J., Takashi J.: Isolation of melatonin and 5-methoxyindole3 -acetic acid from bovine pineal glands. J. Biol. Chemistry 1960, 235, 1992 $-1997$.

26. Mills E., Wu F., Seely D., Guyatt G.: Melatonin in the treatment of cancer: a systemic review of randomized controlled trials and meta-analysis. J. Pineal Res. 2005, 39, 360-366.

27. Poon A. M., Choy E. H., Pang S. F.: Modulation of blood glucose by melatonin: a direct action on melatonin receptors in mouse hepatocytes. J. Biol. Signal Recept 2001, 10, 367-379.

28. Ramracheya R. D., Muller D. S., Squires P. E., Brereton H., Sugden D., Huang G. C., Amiel S. A., Jones P. M., Persaud S. J.: Function and expression of melatonin receptors on human pancreatic islets. J. Pineal Res. 2008, 44, 273-290

29. Reiter R. J., Acuna-Canstroviejo D., Tan D. X., Burkhardi S.: Free radicalmediated molecular damage: mechanism for the protective actions of melatonin in the central neurons system. Analysis of the New Academy of Sciences 2001.

30. Reppert S. M., Schwartz W. J.: Maternal suprachiasmatic nuclei are necessary for maternal coordination of the developing circadian systems. J. Neurosci. 1986, 6, 2724-2729.

31. Reppert S. M., Weaver D. R., Rivkees $S$. A.: Prenatal function and entrainment of a circadian clock. Res. Perinat. Med. 1989, 9, 25-44.

32. Rodriges C., Mayo V. C., Sainz R. M., Antolin I., Herrera F., Martin V., Reiter $J$. R.: Regulation of antioxidant enzymes: a significant role for melatonin. J. Pineal Res. 2004, 36, 1-9.

33. Rokitsky P. F.: Basics of variation statistics for biologists. Minsk 1961.

34. Rowe A. S., Kennaway D. J.: Melatonin in rat milk and the likelihood of its role in postnatal maternal entrainment of rhythms. Am. J. Physiol. Regul. Integrat. Comp. Physiol. 2002, 282, 797-804.

35. Shorokhova I. S., Kislyak N. V., Mariev O. S.: Statistical methods of analysis Ekaterinburg 2015.

36. Simonneaux $V$., Ribelayga C.: Generation of the melatonin endocrine message in mammals: a review of the complex regulation of melatonin synthesis by norepinephrine, peptides and other pineal transmitters. Pharmacol. Rev. 2003, 55, 325-395.

37. Stevens $R$. G.: Artificial lighting in the industrialized world: circadian disruption and breast cancer. Canser Causes Control 2006, 17, 501-507.

38. Tunez I., Munoz M. C., Feijoo M., Valdelvira M. E., Munoz-Castaneda J. R., Montilla P.: Melatonin effect on renal oxidative stress under constant light exposure. Cell Biochem. Funct. 2003, 21, 35-40.

39. Vinogradova I. A., Anisimov V. N., Bukalev A. V., Semenchenko A. V., Zabezhinski M. A.: Circadian disruption induced by light-at-night accelerates aging and promotes tumorigenesis in rat. Aging 2009, 1, 855-865.

40. Zamorsky I. I., Pishak V. P.: Role of non-adrenergic regulation in the reaction of pineal gland on acute hypoxia and epithalamin administration to rat. Probl. Med. Chem. 2000, 1, 28-35.

41. Zamorsky I. I.: Functional organization of the photoperiodic response system of the brain. Adv. Physiol. Sci. 2003, 4, 37-53.

Corresponding author: Konul Hasanova, Animal and Human Physiology Department, Baku State University, Baku, Azerbaijan; e-mail: k0nulhasanova@yandex.ru 